\title{
Residence Rights for EU Citizens and Their Family Members: Navigating the New Normal
}

\author{
Nathan Cambien*
}

\section{Introduction}

Around the time of the Brexit referendum on 23 June 2016, there were around 3.6 million citizens from other EU Member States living in the United Kingdom $^{1}$ and likely around one million UK nationals living in other EU Member States. ${ }^{2}$ Until Brexit, all these citizens were EU citizens and enjoyed, in that capacity, together with their family members, far-reaching rights of free movement and residence. In this connection, it was not required that EU citizens were economically active. EU citizenship grants even non-economically active EU citizens and their family members the right to reside in another Member State under certain conditions. A well-known example are the numerous British pensioners residing in southern Europe: according to estimates, around the time of the Brexit referendum, there were 247,000 UK nationals aged 65 and

* Legal Secretary at the Court of Justice of the European Union; Assistant Professor, University of Antwerp. Many thanks to Elise Muir and Mirna Romić for their valuable comments on an earlier draft. All views expressed are strictly personal.

1 Based on Eurostat figures: see http://appsso.eurostat.ec.europa.eu/nui/show.do?dataset=migr_popictz\&lang=en.

2 A precise estimate is not, to my knowledge available. According the Office for National Statistics (ONS), around 900,00o UK citizens were long-term residents in other EU countries in 2010 and 2011 (Office for National Statistics (2017). What information is there on British migrants living in Europe?. Section 5. Number of British citizens living in Europe in 2011, by age. https://www.ons.gov.uk/peoplepopulationandcommunity/populationandmigration/ internationalmigration/articles/whatinformationisthereonbritishmigrantslivingineurope/ jan2017\#number-of-british-citizens-living-in-europe-in-2011-by-age). More recent figures from the UN show that, in 2017, around 1.3 million people born in the UK were living in other EU Member States (Full Fact (2018). Brits abroad: how many people from the UK live in other EU countries? https://fullfact.org/europe/how-many-uk-citizens-live-other-eu-countries/). See also the discussion in Carrera, S., Guild, E. and Luk, N.C. (2016). What does Brexit mean for the EU's Area of Freedom, Security and Justice? Center for European Policy Studies www. ceps.eu. 
over living in other EU countries, around 121,00o of which were living in Spain alone. $^{3}$

The fate of these rights after Brexit is most uncertain, and has been intensely debated in academic and political circles ever since the Brexit referendum was announced. At the moment of writing this chapter, free movement and residence rights are fully guaranteed by the Withdrawal Agreement until the end of the transition period ${ }^{4}$, but the full set of arrangements governing these rights after that period will still need to be fleshed out. In this chapter, I will try to shed some light on the legal arguments underlying this debate. On the one hand, I will examine arguments deriving from international law or EU law on the basis of which, according to some authors, EU citizens, UK nationals and their family members could continue to enjoy the residence rights attached to citizenship after Brexit. On the other, I will analyse arguments according to which these rights can be protected under an agreement between the UK and the EU and, in particular, legal principles the parties to such an agreement have to take into account.

Throughout this chapter, I will use the expression "EU citizens" to refer to persons having the nationality of one or more of the EU Member States and the expression "UK nationals" to refer to British nationals who, before Brexit, were EU citizens. ${ }^{5}$ Since I will be specifically examining the situation of UK nationals who have lost their EU citizenship after Brexit, I will not analyse the situation of UK nationals who also have the nationality of one or more of the EU Member States. Moreover, as far as the family members of EU citizens are concerned, I will focus on family members coming from third countries, in order to distinguish their situation from that of EU citizens. ${ }^{6}$

3 Office for National Statistics (2017). Pensioners in the EU and the UK. https://www.ons. gov.uk/economy/investmentspensionsandtrusts/articles/pensionersintheeuanduk/2017o9-05.

4 Agreement on the withdrawal of the United Kingdom of Great Britain and Northern Ireland from the European Union and the European Atomic Energy Community, OJ C 384I, 12.11.2019, p. 1-184. The transition period will in principle end on 31 December 2020, but it may be extended. For a detailed discussion, see the Chapter by G. More.

5 Due to the complexity of British nationality laws, not all categories of UK nationals had EU citizenship. See in this regard, the declaration by the United Kingdom of Great Britain and Northern Ireland on the definition of the term "nationals", annexed to the final Act of the Intergovernmental Conference which adopted the Treaty of Lisbon, signed on 13 December 2007 .

6 Some family members of EU citizens are, obviously, EU citizens themselves. 


\section{EU Citizens and Their Family Members: "Autonomous" vs. "Derived" Residence Rights?}

The provisions on EU citizenship, as first introduced by the Maastricht Treaty, are set out in Part Two of the TFEU. It follows from Art. 2O(1) TFEU that every national of a Member State is also an EU citizen. ${ }^{7}$ That provision also sets out the rights enjoyed by EU citizens, the most prominent of which is without a doubt the right to move and reside freely, subject to certain limitations and conditions, within the territory of the Member States. ${ }^{8}$

Not only EU citizens themselves, but also their close family members enjoy a right of free movement and residence in the EU Member States, regardless of whether those family members are EU citizens themselves or not. The categories of family members which enjoy these rights are listed in Art. 2(2) of Directive 2004/38. ${ }^{9}$ There are three categories of such "privileged family members": (i) the spouse or the registered partner of the EU citizen; (ii) the direct descendants of the EU citizen who are under the age of 21 or are dependent and those of the spouse or partner; and (iii) the dependent direct ascendants and those of the spouse or registered partner. ${ }^{10}$ Besides, Art. 3(2) of Directive 2004/38 provides that the Member States have to facilitate entry and residence for what one could call "non-privileged family members", i.e. (i) other family members who, in the country from which they have come, are dependants or members of the household of the Union citizen having the primary right of residence, or where serious health grounds strictly require the personal care of the family member by the Union citizen and (ii)

$7 \quad$ See also Art. 9 TEU.

8 See, e.g., Court of Justice, judgment of 13 July 2017, case C-193/16, E, para. 16.

9 Directive 2004/38/EC of the European Parliament and the Council of 29 April 2004 on the right of the citizens of the Union and their family members to move and reside freely within the territory of the Member States amending Regulation (EEC) No 1612/68 and repealing Directives 64/221/EEC, 68/36o/EEC, 72/194/EEC, 73/148/EEC, 75/34/EEC, 75/35/EEC, 9o/364/EEC, 9o/365/EEC and 93/96/EEC, OJ L 158, 30.4.2004, p. $77^{-123}$.

10 There is some scope for discussion about the precise extent of this category. For instance, according to some authors, the category of ascendant-primary carer could be interpreted broadly to cover non-biological ascendants such as a stepparent or an adoptive parent or even foster parents or unmarried partners. See Barrett, G. (2003). Family Matters: European Community law and Third-country Family Members. Common Market Law Review 40 (2), pp. 369-421, 391, footnote 81, Toner, H. (2004). Partnership Rights, Free Movement and EU Law. Oxford: Hart Publishing, pp. 81-82 and 229-231. 
the partner with whom the Union citizen has a durable relationship, duly attested. ${ }^{11}$ In this chapter, I focus exclusively on the category of "privileged family members".

The conditions governing the right of residence for EU citizens and their family members are further fleshed out in Directive 2004/38. In the most basic terms, every EU citizen is entitled to move to another Member State and reside there, together with his family members for periods exceeding three months if he can prove that he is either economically active or has sufficient financial resources at his disposal. ${ }^{12}$ Essentially, therefore, the right to free movement and residence of EU citizens is subject to two main conditions. ${ }^{13}$ First, it can only be invoked by EU citizens once they leave their Member State and move to another Member State. ${ }^{14}$ Second, EU citizens can only reside in another Member State for longer periods of time if they are self-sufficient, i.e. if they have a job or can fall back on sufficient personal means to support themselves and their family members.

However, in its seminal Ruiz Zambrano judgment, ${ }^{15}$ the Court of Justice held that Art. $20 \mathrm{TFEU}$, in exceptional circumstances, grants even residence rights to EU citizens who do not satisfy these conditions. Indeed, the Court ruled that Art. $20 \mathrm{TFEU}$ precludes national measures, including decisions refusing a right of residence to the family members of an EU citizen, which have the effect of depriving EU citizens of the genuine enjoyment of the substance of the rights conferred on them by virtue of their status as EU citizens. ${ }^{16}$ Accordingly, an EU citizen can derive family reunification rights from EU law where the denial of such rights would deprive him of the genuine enjoyment of his EU citizenship rights even in a situation where he has not left the territory of its Member State and even where he is not economically active or self-sufficient. The Court

11 See, in this regard, Court of Justice, judgment of 5 September 2012, case C-83/11, Rahman and Others. See also Opinion of AG Wathelet delivered on 11 January 2018, case C-673/16, Coman and Others, paras. $83^{-84}$.

12 See Art. 7 of Directive $2004 / 38$.

13 For a discussion, see Cambien, N. (2012). Union Citizenship and Immigration: Re-Thinking the Classics? European Journal of Legal Studies 5 (1), pp. 10-37.

14 See, e.g., Court of Justice, judgment of 12 March 2014, case C-457/12, S. and G., para. 34.

15 Court of Justice, judgment of 8 March 2011, case C-34/o9, Gerardo Ruiz Zambrano v. Office national de l'emploi (ONEm). For a detailed discussion of the case see Hailbronner, K., and Thym, D. (2011). Case C-34/og, Gerardo Ruiz Zambrano v. Office national de l'emploi (ONEm), Judgment of the Court of Justice (Grand Chamber) of 8 March 2011. Common Market Law Review 48(4), pp. 1253-1270.

16 There is an abundant literature on this case law. See, e.g. the contributions in Kochenov, D., ed.(2017). EU Citizenship and Federalism: The Role of Rights. Cambridge: Cambridge University Press. 
of Justice has confirmed and clarified this principle in a number of follow-up cases. ${ }^{17}$

In this connection, the Court has made an important distinction between the nature of the free movement and residence rights of EU citizens, on the one hand, and those enjoyed by their family members who are not EU citizens themselves, on the other hand. While the Treaties confer autonomous rights on EU citizens, the rights conferred on third-country family members are not autonomous rights but rights derived from those enjoyed by the EU citizen. ${ }^{18}$ The purpose and justification of those derived rights are based on the fact that a refusal to allow them would be such as to interfere, in particular, with an EU citizen's freedom of movement. ${ }^{19}$ This distinction is also relevant in the context of the debate about the residence rights that will be enjoyed by EU citizens and their family members after the end of the transition period.

In the following, I will first analyse arguments according to which the residence rights enjoyed by EU citizens and their family members could be considered to be "inalienable" rights which, as such, "survive" Brexit and the transition period. Next, I will analyse the possibility of protecting these rights under an agreement negotiated between the UK and the EU.

\section{Residence Rights Enjoyed by EU Citizens as Inalienable Rights?}

The first question to ask is whether or to what extent the residence rights currently enjoyed by EU citizens and their family members can still be enjoyed after

17 Some of these cases deal with (third country) family members of adult EU citizens: e.g. Court of Justice, judgment of 5 May 2011, case C-434/og, Shirley McCarthy v. Secretary of State for the Home Department, Court of Justice, judgment of 15 November 2011, case C256/11, Murat Dereçi and Others v. Bundesministerium für Inneres. For a discussion, see Shuibhne, N.N. (2012). Case C-434/og, Shirley McCarthy v. Secretary of State for the Home Department, Judgment of the Court of Justice (Third Chamber) of 5 May 2011; Case C-256/ 11, Dereci and others v. Bundesministerium für Inneres, Judgment of the Court of Justice (Grand Chamber) of 15 November 2011. Common Market Law Review 49 (1), pp. 349-379, and Adam, S., and Van Elsuwege, P. (2012). Citizenship Rights and the Federal Balance between the European Union and its Member States: Comment on Dereci. European Law Review (37) 2, pp. 176-19o. Other cases deal with minor EU citizens and their primary carer: e.g. Court of Justice, judgment of 6 December 2012, joined cases C-356/11 and C357/11, O. and S. v. Maahanmuuttovirasto and Maahanmuuttovirasto v. L., Court of Justice, judgment of 10 October 2013, case C-86/12, Adzo Domenyo Alokpa and Others v. Ministre du Travail, de l'Emploi et de l'Immigration.

18 See, e.g., Court of Justice, judgment of 12 March 2014, case C-457/12, S. and G., para. 33.

19 Court of Justice, judgment of 10 May 2017, case C-133/15, Chavez-Vilchez and Others, para. 62 and case law cited. 
the end of the transition period in the absence of an agreement guaranteeing the continued enjoyment of these rights. In this context, it is necessary to make a distinction between, on the one hand, the residence rights enjoyed by UK nationals and their family members in the EU Member States and, on the other hand, the residence rights enjoyed by EU citizens and their family members in the UK.

Residence Rights of UK Nationals and Their Family Members in the $E U$

A number of scholars have argued that the rights attached to EU citizenship are of such a fundamental nature that, once acquired, they can no longer be taken away. ${ }^{20}$ This would mean that the rights enjoyed by UK nationals residing in the EU Member States, would continue to exist after the end of the transition period. Consequently, UK nationals and their family members would continue to have a right of residence in these Member States under the same conditions as those applicable before Brexit.

Two lines of argument have been put forward to defend this point of view. In the first place, it has been pointed out that EU citizenship is, according to settled case law of the Court of Justice, the "fundamental status" of nationals of the Member States. ${ }^{21}$ In its Rottmann judgment, the Court has famously held that a Member State cannot under EU law withdraw its nationality if such withdrawal entails the loss of EU citizenship, unless that withdrawal is in line with general principles of EU law, such as the principle of proportionality. ${ }^{22}$ Hence, it could be argued that once EU citizenship has been acquired, it can no longer be withdrawn, and that, consequently, Brexit cannot entail, for UK nationals, a loss of EU citizenship. ${ }^{23}$ However, according to other authors, this argument fails to convince. One principal reason for this is that, after Brexit, UK nationals are no longer nationals of a Member State,

20 See, e.g., the arguments discussed in the report by Roeben, V., Snell, J., Minnerop, P., Telles, P., and Bush, K. (2017). The Feasibility of associate EU citizenship for UK citizens postBrexit, A study for Jill Evans MEP, available at http://www.jillevans.net/the_feasibility_of_ associate_eu_citizenship_for_uk_citizens_post_brexit.pdf.

21 See, for an early example, Court of Justice, judgment of 20 September 2001, case C-184/99, Grzelczyk, para. 31 .

22 Court of Justice, judgment of 2 March 2010, case C-135/o8, Janko Rottmann v. Freistaat Bayern, paras. 41-59, as recently confirmed in Court of Justice, judgment of 12 March 2019, case C-221/17, Tjebbes. For an analysis, see Cambien, N. (2011). Janko Rottmann v. Freistaat Bayern. Columbia Journal of European Law 17 (2), pp. 375-394.

23 See the discussion in Davies, G. (2016). Union Citizenship - Still Europeans' Destiny After Brexit. European Law Blog, available at http://europeanlawblog.eu/2016/o7/o7/unioncitizenship-still-europeans-destiny-after-brexit/. 
and, as a logical consequence, no longer EU citizens. ${ }^{24}$ That consequence does not derive from the action of a Member State, but flows directly from the Treaties. Indeed, in accordance with Art. 20 TF EU, "Every person holding the nationality of a Member State shall be a citizen of the Union". Moreover, it has been argued that there is nothing in Art. $5^{\circ}$ TEU which provides that, in the event of a withdrawal, the rights attached to EU citizenship should continue to be guaranteed. As Eeckhout and Frantziou point out, at the Constitutional Convention, a number of delegates had proposed amendments that safeguarded existing rights, but these were not adopted. ${ }^{25}$ It can be concluded, therefore, that, considered purely from the perspective of EU law as it currently stands, it is most doubtful that the residence rights enjoyed by UK nationals in the EU in their capacity of EU citizens will survive the end of the transition period.

It should be remarked that there is a possibility that the Court of Justice will have the opportunity to pronounce itself on the legal consequences of Brexit for the rights enjoyed by UK nationals and their family members residing in the EU Member States, if questions for a preliminary ruling on that matter were referred to it. With this purpose, a group of UK nationals living in the Netherlands had seized a Dutch court, which, initially, had agreed to questions to ask the CJEU if Brexit would lead to an automatic loss of rights attached to EU citizenship, in the absence of a negotiated solution agreed between the EU and the UK. ${ }^{26}$ However, after an appeal by the Dutch government, the Dutch court eventually decided not to refer the said questions. ${ }^{27}$ The possibility cannot be

24 See, e.g. Kochenov, D. (2016). Brexit and the Argentinianisation of British Citizenship: Taking Care Not to Overstay Your go Days in Rome, Amsterdam or Paris. Verfassungsblog, available at http://verfassungsblog.de/brexit- and-the-argentinisationof-british-citizenship-taking-care-not-to-overstay-your-9o-days-in-rome-amsterdamor-paris/.

25 Eeckhout, P., and Frantziou, E. (2017). Brexit and Article 50 TEU: A Constitutionalist Reading. Common Market Law Review54 (3), pp. 695-733, 718. See List of Proposed Amendments to the Text of the Articles of the Treaty Establishing a Constitution for Europe, "Part I of the Constitution: Article 59", 39, http://european-convention.europa. eu/docs/Treaty/pdf/46/global46.pdf.

26 Court of Amsterdam,judgment of 7 February 2018,C/13/640244/KG ZA17-1327, available at https://uitspraken.rechtspraak.nl/inziendocument?id=ECLI:NL:RBAMS:2018:605\& showbutton=true\&keyword=brexit.

27 For a discussion, see Garner, O. (2018). Does Member State Withdrawal from the European UnionExtinguishEUCitizenship?C/13/640244/KGZA17-1327 of theRechtbankAmsterdam ('The Amsterdam Case'). European Law Blog available at https://europeanlawblog.eu/ 2018/02/19/does-member-state-withdrawal-from-the-european-union-extinguish-eucitizenship-c13640244-kg-za-17-1327-rechtbank-amsterdam-the-amsterdam-case/. 
ruled out, however, that the matter will come before the Court of Justice or the General Court in the context of a different case. ${ }^{28}$

In the second place, it has been argued that the rights attached to EU citizenship, such as the residence rights for EU citizens and their family members, are covered by the international law doctrine of "acquired rights". ${ }^{29}$ In accordance with that doctrine, international law protects certain rights acquired under a Treaty, notwithstanding the termination of the Treaty. ${ }^{30}$ This doctrine is not only vested in customary international law, ${ }^{31}$ but is also codified to some extent in Art. 70(1)(b) of the Vienna Convention on the Law of Treaties (VCLT), which provides as follows: "Unless the treaty otherwise provides or the parties otherwise agree, the termination of a treaty under its provisions or in accordance with the present Convention, does not affect any right, obligation or legal situation of the parties created through the execution of the treaty prior to its termination". There is little doubt that the VCLT applies to a Member State withdrawing from the EU Treaties under Art. $50 \mathrm{TEU}$.

Some authors argue, on this basis, that certain EU citizenship rights, such as the right of permanent residence, are protected acquired rights. ${ }^{32}$ Most commentators agree, however, that the rights enjoyed by EU citizens under the Treaties are not protected under the doctrine of acquired rights. ${ }^{33}$ On one view, this is because Art. 50 TEU forms a lex specialis which contracts out on international rules on acquired rights, rendering the latter inapplicable in the

28 For a more detailed discussion, see the Chapter by A.P. van der Mei.

29 See, on this issue, European Parliament, Committee on Constitutional Affairs (2017). The impact and consequences of Brexit on acquired rights of EU citizens living in the UK and British citizens living in the EU-27, available at http://www.europarl.europa.eu/ RegData/etudes/STUD/2017/583135/IPOL_STU(2017)583135_EN.pdf; the arguments discussed in the report by Roeben, V., Snell, J., Minnerop, P., Telles, P., and Bush, K. (2017). The Feasibility of associate EU citizenship for UK citizens post-Brexit, A study for Jill Evans MEP, cit.; the arguments discussed in House of Lords, European Union Committee (2016). Brexit: Acquired Rights. House of Lords Paper 82, available at https://publications.parliament.uk/pa/ld201617/ldselect/ldeucom/82/82.pdf.

30 For a discussion, see, e.g., Sik, K. (1977). The Concept of Acquired Rights in International Law: A Survey. Netherlands International Law Review 24 (1-2), pp. 120-142.

31 See Lalive, P.A. (1965). The Doctrine of Acquired Rights. In: Bender, ed., Rights and duties of private investors abroad. New York: International and comparative law center, p. 183.

32 Waibel, M. (2017). Brexit and Acquired Rights. AJIL Unbound 111, available at https://www. researchgate.net/publication/322311461_Brexit_and_Acquired_Rights, pp. 440-444.

33 See, e.g., Repasi, R. (2017). Die Rechte der Unionsbürger und ihr Fortbestehen nach dem Brexit. ifo Schnelldienst 70 (11), pp. 30-33, Douglas-Scott, S. (2016). What Happens to "Acquired Rights" in the Event of a Brexit? U.K. Constitutional Law Blog, available at https://ukconstitutionallaw.org/; Piris, J.C. (2015). Should the UK withdraw from the EU: legal aspects and effects of possible options. European Issues 355, p. 10. 
case of a Member State withdrawal from the EU. In this connection, it has been observed that Art. 70(1) VCLT explicitly states "Unless the treaty otherwise provides or the parties otherwise agree". ${ }^{34}$ Another reason relied on to support this view is that under the VCLT, EU citizens are third parties with respect to the EU treaties, while Art. $7 \mathrm{O}(1)(\mathrm{b})$ of the VCLT only applies to the rights, obligations, or legal situations of the state parties to the EU Treaties. In this connection, it can be pointed out that the International Law Commission, in its commentary on the scope of the identically worded predecessor to Art. 70.1(b) (Art. $66 \mathrm{draft}$ Vienna Convention) clarified that:

On the other hand, by the words 'any right, obligation or legal situation of the parties created through the execution of the treaty', the Commission wished to make it clear that paragraph l(b) relates only to the right, obligation or legal situation of the States parties to the treaties created through the execution, and is not in any way concerned with the question of the 'vested interests' of individuals. ${ }^{35}$

It follows that it is unlikely that the international law doctrine of acquired rights could be successfully relied upon after the end of the transition period by UK nationals and their family members residing in the EU Member State in order to preserve the full spectrum of residence rights attached to EU citizenship.

\section{Residence Rights of EU Citizens and Their Family Members in the UK}

The situation, after Brexit, of EU citizens residing in the UK is different from that of UK nationals residing in one of the 27 Member States. Indeed, in contrast to the latter group, EU citizens preserve their EU citizenship, in accordance with Art. 20 TFEU and Art. 9 TEU, even after Brexit. However, the arguments for considering that EU citizens could preserve the full spectrum of their residence rights in the UK on the basis of EU law in the absence of a negotiated solution, would not appear to be altogether convincing.

First of all, since the UK is no longer a Member State after Brexit, it is no longer bound by EU law, neither by primary law provisions on EU citizenship nor by secondary EU law, such as Directive 2004/38. Consequently, EU citizens residing in the UK will no longer be able to rely on their EU citizenship rights

34 See, e.g., House of Lords (2017). Brexit and the EU Budget. House of Lords Paper 125, available at https://publications.parliament.uk/pa/ld201617/ldselect/ldeucom/125/125.pdf. 
in the UK, which in, in effect, has become a third country. It does not appear that there is a provision of EU law, including Art. 50 TFEU, which allows them to continue to enforce these rights before national courts in the UK or before the CJEU, which will no longer have jurisdiction over the UK.

Second, it is not evident, for the same reasons as those outlined above, that the international law doctrine of acquired rights could be successfully relied upon after Brexit by EU citizens and their family members residing in the UK in order to preserve the full spectrum of their residence rights attached to EU citizenship.

\section{$3 \quad$ Intermediary Conclusion}

It follows from the analysis above that it is far from certain that the various arguments discussed in order for EU citizens and their family members to be able to continue to rely (fully) on the residence rights would succeed if they were invoked before a national court, for instance by a UK national who wanted to continue to enjoy his residence rights as an EU citizen in one of the EU Member States after the end of the transition period. If, indeed, the residence rights attached to EU citizenship cannot be considered to be "acquired" rights, which continue to be enforceable after Brexit, these rights only continue to be enjoyed if that is provided for in an agreement negotiated between the EU and the UK. That possibility will be analysed in part 4 , below.

For the sake of completeness, it must be pointed out that, if no negotiated solution would be reached between the EU and the UK governing the situation after the end of the transition period, UK nationals and their family members, residing in the EU Member States, would, in any event, still enjoy the rights conferred by the EU on third country nationals. More in particular, they would enjoy the residence rights governed by a number of directives, such as the Family Reunification Directive, ${ }^{36}$ the Long Term Residence Directive ${ }^{37}$ or the Blue Card Directive. ${ }^{38}$ The conditions laid down in these directives are, however, less beneficial than those governing the residence rights of EU citizens and their family members. ${ }^{39} \mathrm{EU}$ citizens residing in the UK, by contrast, would

36 Council Directive $2003 / 86 /$ EC of 22 September 2003 on the right to family reunification, OJ L 251, 3.10.2003, p. 12-18.

37 Council Directive 2003/109/EC of 25 November 2003 concerning the status of thirdcountry nationals who are long-term residents, OJ L 16, 23.1.2004, p. 44-53.

38 Council Directive 2009/50/EC of 25 May 2009 on the conditions of entry and residence of third-country nationals for the purposes of highly qualified employment, OJ L 155, 18.6.2009, p. 17-29.

39 For an analysis, see inter alia Mindus, P. (2017). European Citizenship after Brexit: Freedom of Movement and Rights of Residence. Palgrave Macmillan, ch. 3 . 
no longer have a claim to any rights derived under EU law. As third country nationals, they could still derive residence rights under UK law, but the conditions governing these would likely be stricter in many circumstances than those governing their prior residence rights as EU citizens. ${ }^{40}$

Moreover, both groups of citizens could still derive rights from the ECHR, since both the UK and all the EU Member States are party to that convention and will continue to be parties for the foreseeable future. In this connection, some scholars have argued that the rights enjoyed by EU citizens up until Brexit will be "cemented" and protected after Brexit under the ECHR. ${ }^{41}$ More particularly, as far as residence rights are concerned, reference is made to the judgment of the European Court of Human Rights in Case Kurić and others v. Slovenia, ${ }^{42}$ which concerns the rights of former nationals of Yugoslavia in Slovenia. In that case, that Court held that Slovenia had breached Art. 8 ECHR by suddenly taking away the rights of certain groups of these nationals. In this connection, it pointed out (at para. 355 of the judgment) that "measures restricting the right to reside in a country may, in certain cases, entail a violation of Art. 8 of the Convention if they create disproportionate repercussions on the private or family life, or both, of the individuals concerned". However, it is well-known that Art. $8 \mathrm{ECHR}$ allows Member States a rather broad margin of discretion and it seems fair to say that the residence rights enjoyed by EU citizens and their family members are not entirely protected under Art. 8 EC HR. ${ }^{43}$ In addition, specifically as regards UK nationals, it is sometimes argued that the ECHR can be relied upon, in certain circumstances, to prevent the withdrawal of EU citizenship. While it is true that the European Court of Human Rights has held that, in certain circumstances, the loss of citizenship may fall within the ambit of Art. $8 \mathrm{ECHR},{ }^{44}$ it cannot be inferred with certainty from

40 See the discussion in Schrauwen, A. (2017). (Not) losing out from Brexit. Europe and the World: A Law Review 1 (1), available at http://hdl.handle.net/11245.1/c8ab4b3b-eedf-4b67bf56-23b3eao53f2o, pp. 8-13 and in Kilkey, M. (2017). Conditioning Family-life at the Intersection of Migration and Welfare: The Implications for 'Brexit Families'. Journal of Social Policy 46(4), pp. 797-814.

41 See, e.g., González, G.M. (2016). "Brexit" Consequences for Citizenship of the Union and Residence Rights. Maastricht Journal of European and Comparative Law 23 (5), pp. 796-811.

42 European Court of Human Rights, judgment of 26 June 2012, no. 26828/o6, Kurić and Others v. Slovenia.

43 See Schrauwen, A. (2017). (Not) losing out from Brexit, cit., p. 6: "Thus in any event the doctrine would not apply to those who have not yet acquired the right to permanent residence, and might imply a weaker position for those who recently decided to move abroad, arguably for the most part young people".

44 See, e.g., European Court of Human Rights, decision of 7 February 2017, no. 42387/13, K2 v. the United Kingdom. 
that case law that the loss of EU citizenship would be in breach of Art. $8 \mathrm{ECHR}$, especially given the fact that the said case law is concerned with national citizenship. According to the House of Lords European Union Committee, it may be concluded that Art. $8 \mathrm{ECHR}$ cannot be relied on to prevent the status of EU citizenship from being removed as a consequence of Brexit. ${ }^{45}$

In conclusion: while arguments derived from the ECHR would perhaps be more successful than arguments relying exclusively on EU law or the international law doctrine of acquired rights, these arguments do not provide a solid basis to fully protect the residence rights currently enjoyed by EU citizens and their family members. A comprehensive solution could only be reached by an agreement concluded between the UK and the EU.

Brexit and Residence Rights: an Essential Issue for Any Negotiated Solution

The idea of negotiating a new set of rules to resolve some of the UK's concerns regarding the EU legal framework is not a new phenomenon, of course. It is well-known that the UK has managed to negotiate so-called "op-outs" in important areas of EU law, including in the so-called Area of Freedom, Security and Justice. When then Prime Minister David Cameron decided to hold the "Brexit" referendum, his idea was to achieve a new "deal" with the EU before the date of that referendum, a deal intended to sway many of the UK concerns regarding the impact and working of the $\mathrm{EU}$, and, as a consequence, to convince a majority of voters to stay in the EU. Not surprisingly, the new deal focused to a large extent on free movement and EU citizenship related issues. The European Council conclusions of February 2016 stated, inter alia, that the references in the Treaties and their preambles to the process of creating "an ever closer union among the peoples of Europe" would not apply to the United Kingdom, and they proposed to amend the existing rules on EU citizens and their family members in order to make them somewhat more restrictive. ${ }^{46} \mathrm{An}$ nexed to these conclusions was a declaration in which the Commission set out

45 House of Lords, European Union Committee (2016). Brexit: Acquired Rights, cit; Mindus, P. (2017). European Citizenship after Brexit: Freedom of Movement and Rights of Residencecit., ch. 7, p. 108.

46 See the European Council Conclusions of 18 and 19 February 2016, A new settlement for the United Kingdom within the European Union and the Decision of the Heads of State or Government, meeting within the European Council, concerning a new settlement for the United Kingdom within the European Union, in Annex 1 of European Council Conclusions of 18-19 February 2016. 
its intention to adopt a proposal to complement Directive 2004/38 in order to exclude from the scope of free movement rights certain third country nationals resorting to an abuse of rights. ${ }^{47}$

However, the proposed settlement was rejected when, on 23 June 2016, a small majority of British votes was cast in favour Brexit. On 29 March 2017, the United Kingdom officially notified the European Council of its intention to leave the European Union. In accordance with Art. 50 TEU this notification was followed by negotiations to set out the precise arrangements for withdrawal. These negotiations could last, in principle, no more than two years, ${ }^{48}$ but they could be extended in common accord. Accordingly, the initial deadline of 29 March 2019 was extended to 31 October $2019 .{ }^{49}$ Moreover, both sides have agreed to have subsequent to the negations a so-called "transition period" in order to avoid an abrupt change of the legal regime applicable to the UK and the EU Member States.

As far as the EU is concerned, it was apparent from the outset that EU citizenship would have to play a central role in these negotiations, as is clearly stated, for instance, in the guidelines for Brexit negotiations of the European Council ${ }^{50}$ and the negotiation directives of the Council. ${ }^{51}$ In fact, the Council, the European Parliament and the Commission repeatedly stated that one of the first priorities for the negotiations would be to agree on guarantees to protect the rights of EU citizens, and their family members, that are affected by Brexit. For instance, the Council's press release of 22 May 2017 explicitly stated that the first priority for the negotiations is to agree on guarantees to protect the rights of EU and UK citizens, and their family members, that are affected

47 See the Declaration of the European Commission on issues related to the abuse of the right of free movement of persons, in Annex 7 of European Council Conclusions of 18-19 February 2016. For a more in-depth analysis, see the chapter by E. Muir.

48 See Art. 5O(3) TEU, which provides: "The Treaties shall cease to apply to the State in question from the date of entry into force of the withdrawal agreement or, failing that, two years after the notification referred to in paragraph 2, unless the European Council, in agreement with the Member State concerned, unanimously decides to extend this period".

49 See European Council decision taken in agreement with the United Kingdom of 11 April 2019 extending the period under Article 50(3)TEU.

$50 \quad$ European Council Guidelines of 29 April 2017, following the United Kingdom's notification under Article $50 \mathrm{TEU}$, available at: http://www.consilium.europa.eu/en/press/pressreleases/2017/04/29-euco-brexit-guidelines/.

$5^{1}$ Council Directives of 22 May 2017 for the negotiation of an agreement with the United Kingdom of Great Britain and Northern Ireland setting out the arrangements for its withdrawal from the European Union, available at: http://www.consilium.europa.eu/en/ press/press-releases/2017/05/22-brexit-negotiating-directives/. 
by Brexit. ${ }^{52}$ At the same time, the UK made it clear from the outset that it wants to limit the rights of EU citizens and their family members in the UK, in particular their right to free movement and residence. Accordingly, a white paper published in February 2017 by the UK government stated unequivocally: "We will design our immigration system to ensure that we are able to control the numbers of people who come here from the EU. In future, therefore, the Free Movement Directive will no longer apply and the migration of EU nationals will be subject to UK law". ${ }^{3}$

It is inevitable, therefore, that, in the context of the Brexit negotiations, the concept of EU citizenship, which is destined to be the fundamental status of all Member State nationals, was deeply challenged. It remains to be seen how the concept of EU citizenship and the rights attached to it emerge from the negotiations.

While Part Two of the Withdrawal Agreement governs the residence rights of EU citizens, UK nationals and their family members which were triggered before of the end of the transition period, arrangements governing future residence rights will have to be set out in an agreement on the future EU-UK Partnership, to be negotiated and concluded during the transition period. The aim of this section is not to provide a critical analysis of the current state of negotiations, and neither to predict their outcome. At the moment of the writing of this chapter, it is impossible to know what the outcome of the negotiations will be, or even to know whether a negotiated solution will be reached, in particular since, in order to do so, a number of important hurdles must still be overcome. ${ }^{54}$ Moreover, even the arrangements set out in the Withdrawal Agreement could (partially) disappear, if a pending challenge against it before the General Court would be successful ${ }^{55}$. Rather, this section purports to examine, from a legal point of view, some of the legal principles that any negotiated solution would have to take into account, including the Withdrawal Agreement and its implementation schemes.

$5^{2}$ Council (Art 50) authorises the start of Brexit talks and adopts negotiating directives, in Council Press release 286/17 of 22 May 2017, available at http://www.consilium.europa.eu/ en/press/press-releases/2017/05/22/brexit-negotiating-directives/.

See, the Government of the United Kingdom (2017). The United Kingdom's exit from and new partnership with the European Union - White Paper, available at https://www. gov.uk/government/publications/the-united-kingdoms-exit-from-and-new-partnershipwith-the-european-union-white-paper, 5.4.

54 For a general discussion of some of these hurdles, see Editorial comments: Polar exploration: Brexit and the emerging frontiers of EU law (2018). Common Market Law Review 55 (1), p. $1-16$. 


\section{$1 \quad$ Changing Citizenship Statuses at the EU Level}

One radical - though given the current political context mostly theoretical way of dealing with the issue of residence rights for EU citizens after Brexit would be to change the status of citizenship at the EU level, or the access to it, in such a way that after Brexit, UK nationals remain citizens of the EU, and preserve the current rights associated to that status. Various options can be considered in this connection. ${ }^{56}$ I will limit myself to discussing the three most important ones.

The first option would be to turn EU citizenship into a truly independent form of citizenship, by decoupling it from Member State nationality. ${ }^{57}$ In other words: having the nationality of a Member State would no longer be required in order for a person to be an EU citizen. Such an arrangement could allow UK nationals to remain EU citizens after Brexit, and hence to continue to enjoy the residence rights attached to that status in the EU Member States. This first option might be very interesting from an academic point of view, but it is, to my mind, not viable from a political perspective, for a number of reasons. First of all, implementing this option would require changing the Treaties, and in particular Art. 9 TEU and Art. 20 TFEU. However, it is clear from the available documents that the Member States, at the time of the conclusion of the Maastricht Treaty, were not prepared to have an independent form of EU citizenship which would potentially become more important than their own nationality. Hence the clear wording of Art. 9 TEU and Art. 20 TFEU to the effect that "Citizenship of the Union shall be additional to and not replace national citizenship". It is unlikely that in the current context, in which anti-EU feelings have grown in intensity compared to past decades, Member States would change their mind on this issue. Moreover, even in the implausible event that Member States would be willing to make the said Treaty changes, those changes would not do anything to guarantee the residence rights of EU citizens in the UK, which will become a third country after Brexit. From a political perspective, the said Treaty changes would only be acceptable, therefore, if the UK would reciprocate by accepting to continue to guarantee the current residence and

$5^{6}$ See the discussion in Kochenov, D. (2016). EU Citizenship and Withdrawals from the Union: How Inevitable Is the Radical Downgrading of Rights?. LSE 'Europe in Question' Discussion Papers Series No.111/2016., available at http://www.lse.ac.uk/europeanInstitute/LEQS\%2oDiscussion\%2oPaper\%2oSeries/LEQSPaperı11.pdf.

57 This idea has been suggested for a long time by some legal scholars. See the literature referred to in Kostakopoulou, D. (2017). Scala Civium: Citizenship Templates Post-Brexit and the European Union's Duty to Protect EU Citizens Journal of Common Market Studies 56 (4), pp. 854-869, 858 . 
free movement rights attached to EU citizenship for EU citizens. However, that commitment would clearly go against the intentions repeatedly stated by the UK government and would, at least for some people, defeat the purpose of Brexit.

A second option would be to create a form of "associate citizenship" for UK nationals, which would allow UK nationals to keep (some of) the rights associated with EU citizenship after Brexit. ${ }^{58}$ This option would be less farreaching than the first one, as it would not change the EU citizenship status as such, but would entail the creation of a separate status, with possibly more limited and a more static set of rights. ${ }^{59}$ Moreover, acquiring this status could be made subject to an individual opt-in, by UK nationals satisfying certain conditions, such as, for instance, the payment of a fee..$^{60}$ This second-option, while it would most likely also require an amendment of the Treaties, ${ }^{61}$ would not require an overhaul of the existing EU citizenship concept, as interpreted in the case law of the European Court of Justice. Still, from a political level, granting associate citizenship to (certain) UK nationals would likely be acceptable only if the UK reciprocated, for instance by granting a form of associate British citizenship. ${ }^{62}$ However, such reciprocal commitments are considered to be problematic by many observers, ${ }^{63}$ for the same reasons as outlined above.

A third option would be to facilitate access to EU citizenship for UK nationals after Brexit, for instance by granting the right to UK nationals residing for more than five years in a given Member State to obtain the nationality of that Member State - and, therefore, EU citizenship - by mere registration or

$5^{8}$ See the discussion in Miller, V. (2018) Brexit and European Citizenship. House of Commons Briefing Paper $n^{\circ} 8365$, available at https://researchbriefings.files.parliament.uk/documents/CBP-8365/CBP-8365.pdf, pp. 24 et seq.

59 For a critical discussion, see Van den Brink, M, and Kochenov, D. (2019) Against Associate EU Citizenship. Journal of Common Market Studies.

6o See e.g. European Parliament Draft Report of 9 November 2016, Possible evolutions of and adjustments to the current institutional set-up of the European Union, amendment nr. 882 by MEP Charles Goerens, available at http://www.europarl.europa.eu/sides/ getDoc.do?pubRef=-//EP//NONSGML+COMPARL+PE-592.348+O2+DOC+PDF+Vo// EN\&language $=\mathrm{DE}$.

61 See the discussion in Roeben, V., Snell, J., Minnerop, P., Telles, P., and Bush, K. (2017). The Feasibility of associate EU citizenship for UK citizens post-Brexit, A study for Jill Evans MEP, cit.

62 See the discussion in Roeben, V., Snell, J., Minnerop, P., Telles, P., and Bush, K. (2017). The Feasibility of associate EU citizenship for UK citizens post-Brexit, A study for Jill Evans MEP, cit.

63 See, e.g., the chapters by A.P. van der Mei and G. More in this special issue. 
declaration. ${ }^{64}$ This option, while again interesting from an academic perspective, is problematic for a number of reasons. First, it would require harmonisation, to some extent, of Member State nationality laws, something that is unlikely to be accepted by the Member States. Indeed, so far the Member States have always resisted any interference of EU legislation in their nationality laws. This has led the Court of Justice to hold that it is for each Member State to lay down the conditions for the acquisition and loss of nationality, while at the same time, Member States must unconditionally recognize each other's nationality. ${ }^{65}$ Second, this solution could be problematic in Member States which do not allow dual nationality, because in those Member States UK nationals would lose their UK nationality upon acquiring the nationality of their host Member State, which would present them with a difficult choice between two less than satisfactory options. Third, there is the issue of the absence of reciprocity on behalf of the UK.

Preserving Residence Rights for EU Citizens/UK Nationals and Their Family Members

If the (access to the) citizenship status at EU level is left unchanged, the residence rights of EU citizens and UK nationals after Brexit become the subject of the negotiations between the EU and the UK. The content of any agreement will be based to a large extent on political considerations. Yet, the negotiators also have to take into account a number of legal principles which are, arguably, relevant for the subject of residence rights after Brexit, as I will examine in what follows. The negotiated solution has to deal, on the one hand, with the situation of EU citizens who have moved to the UK or UK nationals who have moved to another Member State before Brexit (or before the end of the transition period) and, on the other hand, of those EU citizens or UK nationals who will move after Brexit (or after the end of the transition period). In this section, I am dealing mostly with the situation of persons who have moved before Brexit (or before the end of the transition period), as, in my view, this group has the strongest claims on the basis of the said principles.

EU citizens and their family members who move to another Member State can enjoy three different types of residence rights, which are subject to different conditions. First, EU citizens and their family members can move to another Member State and reside there for periods up to three months without any conditions or any formalities other than the requirement to hold a valid

\footnotetext{
64 Kostakopoulou, D. (2017). Scala Civium:Citizenship Templates Post-Brexit and the European Union's Duty to Protect EU Citizens, cit., p. 8.

65 Court of Justice, judgment of 7 July 1992, case C-369/9o, Micheletti e.a., para. 10.
} 
identity card or passport (see Art. 6 of Directive 2004/38). Second, for periods of residence longer than three months, they must, as was pointed out above, be economically active or self-sufficient (see Art. 7 of Directive 2004/38). Third, the strongest, most complete form of residence right is the so-called "permanent residence", which is acquired, in principle, after the Union citizen has resided legally for a continuous period of five years in the host Member State. ${ }^{66}$

As I will analyse in what follows, there are a number of legal principles which the Withdrawal Agreement and its implementation schemes would, according to some scholars, have to respect and which, arguably, could provide arguments to the effect that EU citizens who reside in the UK or UK nationals having a right of residence in one of the EU Member States, especially those having acquired of right of permanent residence, would be entitled to preserve this under the agreement. Some of these legal principles are, in my view, binding on both the UK and the EU Member States, whereas other legal principles only bind the latter.

First of all, the Withdrawal Agreement and its implementation schemes have to respect fundamental rights as laid down in the European Convention of Human Rights, to which both the UK and the EU Member States are a party. ${ }^{67}$ The right to protection of family life laid down in Art. 8 ECHR precludes, under certain circumstances, residence rights being taken away. In this regard, the degree of integration in the host State certainly is a relevant consideration in assessing whether deportation is allowed under Art. 8 ECHR. Hence, this argument could work in favour, especially of UK nationals having acquired a right of permanent residence in one of the EU Member States or EU citizens who are integrated in the UK.

Second, one could argue that "integration" itself is a guiding legal principle of EU law. In this context, one could refer to the objective stated in the preamble to the TEU of continuing "the process of creating an ever closer union among the peoples of Europe". The free movement of EU citizens plays a very important role for the achievement of this objective, and one could argue that respecting this principle requires to some extent guaranteeing residence rights for UK nationals in the EU Member States after the end of the transition period. Again, this argument seems to be most convincing with regard to UK nationals having acquired a right of permanent residence. In this connection, it should be pointed out that recitals 17 and 18 of the preamble to Directive

66 See Art. 16 of Directive 2004/38. See also the derogations laid down in Art. 17 of the Directive 2004/38.

67 See also supra, under III.3. for an analysis of the implications of the EcHR even in the absence of a withdrawal agreement. 
2004/38 make it clear that permanent residence is a key element in promoting social cohesion, which is one of the fundamental objectives of the Union and that in order to be a genuine vehicle for integration into the society of the host Member State in which the Union citizen resides, the right of permanent residence, once obtained, should not be subject to any conditions. As such, this legal principle could provide some support for the view that, UK nationals who are sufficiently integrated in the society of one of the home Member States should be entitled to residence in the EU even after Brexit. A similar argument could not be made in favour of EU citizens residing in the UK, since the UK will no longer be bound by any "integration" principle.

Third, the implementation of the Withdrawal Agreement should take into account the principle of legitimate expectations to claim a continued right of residence. ${ }^{68}$ According to settled case-law of the Court, the principle of the protection of legitimate expectations is one of the fundamental principles of the European Union and must be observed not only by the EU institutions, but also by Member States in the exercise of the powers conferred on them under EU directives. The right to rely on that principle extends to any person in a situation in which an administrative authority has caused that person to entertain expectations which are justified by precise assurances provided to him. ${ }^{69}$ It could be argued, on this basis, that UK nationals and their family members who had acquired a permanent right of residence in one of the EU Member States or were on track to acquire this, have a legitimate expectations that they would be able to continue to reside there. However, it would seem that the principle would not have to be taken into account by the UK as regards EU 27 citizens residing in the UK. This argument is implicit in the policy paper of the UK government, entitled "Safeguarding the position of EU citizens in the UK and UK nationals in the EU",70 which states that "those EU citizens who arrived after the specified date will be allowed to remain in the UK for at least a temporary period and may become eligible to settle permanently, depending on their circumstances - but this group should have no expectation of guaranteed settled status"71.

68 See in this regard the discussion in Garner, O. (2018). Does Member State Withdrawal from the European Union Extinguish EU Citizenship? C/13/64O244 / KG ZA 17-1327 of the Rechtbank Amsterdam ('The Amsterdam Case'), cit.

69 Court of Justice, judgment of 26 July 2017, case C-56o/15, Europa Way and Persidera, paras $79-8$ o.

70 Government of the United Kingdom(2017). The United Kingdom's exit from the European Union: safeguarding the position of EU citizens living in the UK and UK nationals living in the EU, available at https://www.gov.uk/government/publications/ safeguarding-the-position-of-eu-citizens-in-the-uk-and-uk-nationals-in-the-eu. See however, Art. 15 of the Withdrawal Agreement. 
Fourth, one could add that if the Withdrawal Agreement would not guarantee the continued right of permanent residence after Brexit for UK nationals in the EU Member States under the same conditions as currently applicable, the effet utile of that right would be compromised. Admittedly, that right, as such would no longer be applicable to them. However, one could argue that, by suddenly taking away this right, one would compromise the effet utile of the build-up of that right which happened in tempore non suspecto, i.e. before Brexit. Indeed, UK nationals who moved to one of the EU Member States with a view to residing there in accordance with the conditions laid down in Directive 2004/38 will have done so with a view to settling in that Member State and to creating and strengthening family life in that State. ${ }^{72}$ This whole purpose, which was in most case undertaken before any realistic prospect of Brexit came about, would, arguably be defeated if, after Brexit, the said nationals would be stripped of their right of residence. The effet utile of EU law is, therefore, another principle which the negotiating parties have to take into account when reaching an agreement on the residence rights of EU citizens and their family members. As was the case for the second principle discussed above, this principle could be invoked by UK nationals living in the EU, but not, conversely, by EU citizens in the UK, as the UK will arguably no longer have an obligation under EU law to respect the effet utile of provisions of EU law.

In this connection, it must be pointed out that, since Directive 2004/38 will no longer apply as such to UK nationals after the end of the transition period, they could be made subject to certain administrative formalities in order to have their permanent right of residence as an EU citizen transformed into a similar right on the basis of the withdrawal agreement. However, those formalities should not be overly burdensome, in order not to compromise the effet utile of the right of permanent residence. Interesting to note in this regard is that paragraph 23 of the joint technical notes on EU-UK positions on citizens' rights that have been published after the second and third round of negotiations $^{73}$ stated: "In order to obtain status under the Withdrawal Agreement by application, those already holding a permanent residence document issued under Union law at the specified date will have that document converted into

72 Court of Justice, judgment of 12 March 2014, case C-56o/15, O., para. 54. For a discussion, see Cambien, N. (2014). Cases C-456/12 O. and B. and C-457/12 S. and G.: Clarifying the inter-state requirement for EU citizens?. European Law Blog, available at http://europeanlawblog.eu/2014/04/11/cases-c-45612-o-and-b-and-c-45712-s-and-g-clarifying-the-interstate-requirement-for-eu-citizens/.

73 These joint technical notes are available at https:/ec.europa.eu/commission/brexitnegotiations/negotiating-documents-article-5o-negotiations-united-kingdom_en. 
the new document free of charge, subject only to verification of identity, a criminality and security check and confirmation of ongoing residence". Similarly, Art. 18(1)(h) of the Withdrawal Agreement provides that "persons who, before the end of the transition period, hold a valid permanent residence document issued under Article 19 or 20 of Directive 2004/38/EC or hold a valid domestic immigration document conferring a permanent right to reside in the host State, shall have the right to exchange that document [...] for a new residence document upon application after a verification of their identity, a criminality and security check [...] and confirmation of ongoing residence; such new residence documents shall be issued free of charge". It could be wondered whether, in order fully to preserve the effet utile of the right to permanent residence, this exchange of documents should not happen in a more automatic fashion. ${ }^{74}$

Fifth, another principle which has to be taken into account, by the EU side, is the principle of equal treatment and non-discrimination, which is a general principle of EU law, and which is also laid down in Arts 20 and 21 of the Charter. More in particular, the arrangements governing the residence rights for UK nationals and their family members should obviously not be more disadvantageous than those applying to other third country nationals, except where these nationals can benefit from certain advantageous arrangements in, for instance, association agreements with the EU. ${ }^{75}$ As such, the principle of equal treatment and non-discrimination provides a sort of lower limit: negotiating residence rights for UK nationals after the transition period which fall short of those already enjoyed by third country nationals, does not seem to be possible.

\section{Concluding Remarks}

The precise arrangements governing the residence rights of EU citizens and their family members after the transition period will be governed by the Withdrawal agreement and, possibly, by an agreement on the future EU-UK Partnership to be concluded between the EU and the UK. Those arrangements will in any event have to respect a number of key legal principles discussed in this

74 See the criticisms voiced by Peers, S. (2018). EU and UK citizens' acquired rights in the Brexit withdrawal agreement: detailed analysis and annotation. EU Law Analysis, available at http://eulawanalysis.blogspot.lu/2018/o3/eu27-and-uk-citizens-acquired-rights-in.html.

75 See the examples given in Kochenov, D. (2016). Brexit and the Argentinianisation of British Citizenship: Taking Care Not to Overstay Your 9o Days in Rome, Amsterdam or Paris, cit. 
chapter. Moreover, there is little doubt that, on a political level, any residence rights granted to UK nationals and their family members would only be accepted by the EU if the UK reciprocates and grants equal residence rights to EU citizens and their family members. This paper has not examined in detail the situation of EU citizens and UK nationals who move after Brexit. It would seem that they cannot, or not to the same extent, rely on the legal principles examined to continue to enjoy the same residence rights as those applicable before Brexit and it is likely that their rights will be restricted compared to the current residence rights enjoyed by EU citizens.

This chapter has focused on the issue of residence rights. For the sake of completeness, it should be pointed out that, besides residence rights, there is the issue of the free movement between Member States. The most pressing question in this regard, is the following one: will UK nationals and their family members who enjoy a right of residence in one of the EU Member States after the end of the transition period, equally have the right to freely move between and reside in other EU Member States? This issue may find a negotiated solution in an agreement on the future EU-UK Partnership. It would seem that the arguments examined above are not conclusive in this regard. Obviously, the principle of equal treatment precludes granting UK nationals more restrictive free movement rights than those generally enjoyed by third country nationals. Yet those rights are considerably less in scope than those enjoyed by EU citizens. Moreover, as Kochenov has pointed out, the UK is not in a position to reciprocate on free movement rights, since it is leaving the EU on its own. ${ }^{76}$ Interesting to note in this connection is that Art. 32 of the draft Withdrawal Agreement of 15 March 2018 provided as follows: "In respect of United Kingdom nationals and their family members, the rights provided for by this Part shall not include further free movement to the territory of another Member State, the right of establishment in the territory of another Member State, or the right to provide services on the territory of another Member State or to persons established in other Member States".

One option that could be envisaged as a solution to the residence and free movement-related issues after the end of the transition period is a carefully tailored most favoured nation clause and a requirement of reciprocal treatment. In international law, reciprocal treatment is primarily envisaged as a means of protecting nationals or things, ${ }^{77}$ although most-favoured-nation clauses

76 Kochenov, D. (2018). Misguided 'Associate EU Citizenship' Talk as a Denial of EU Values. Verfassungsblog, availableathttps://verfassungsblog.de/misguided-associate-eu-citizenshiptalk-as-a-denial-of-eu-values/.

77 International Law Commission, Draft Articles on most-favoured-nation clauses with commentaries, Yearbook of the International Law Commission, Vol. II., part two, 1978, p. 17. 
are nowadays primarily used in the wTO context, as well as in the bilateral trade and investment treaties. ${ }^{78}$ The said clauses are defined in the broadest of terms ${ }^{79}$ which is why they should be used with caution. ${ }^{80}$ When it comes to the EU, these types of clauses are often found in bilateral cooperation agreements, such as the one between the EU and the member parties to the Cartagena Agreement. ${ }^{81}$ The downside of these types of clauses is that they can seldom be relied upon directly by the individuals..$^{82}$ If this type of a clause were to be introduced into an agreement with the UK, UK citizens moving to and living in the EU, but also EU citizens moving to and living in the UK could be granted preferential treatment in certain respects (e.g. free movement and residence rights similar to those enjoyed by EU citizens in the EU Member States) while no longer being entitled to the rights currently enjoyed by EU citizens in others.

78 International Law Commission, Final Report of the Study Group on the Most-FavouredNation Clause, Yearbook of International Law Commission, Vol. II., part two, 2015, p. 2.

79 Radi, Y. (2007). The Application of the Most-Favoured-Nation Clause to the Dispute Settlement Provisions of Bilateral Investment Treaties: Domesticating the "Trojan Horse" European Journal of International Law 18 (4), pp. 757-774, $75^{8}$.

8o International Law Commission, Draft Articles on most-favoured-nation clauses with commentaries, cit., p. 20.

81 Council Regulation 1591/84 of 4 June 1984 concerning the conclusion of the Cooperation Agreement between the European Economic Community, of the one part, and the Cartagena Agreement and the member countries thereof - Bolivia, Colombia, Ecuador, Peru and Venezuela - of the other part, OJ L 153, 8.6.1984, p. 1-1.

82 Although the Court of Justice did not definitively exclude such a possibility for the mostfavoured-nation clause in general, the clause was not given direct effect in its judgment of 2o May 2010, case C-16o/og, Ioannis Katsivardas - Nikolaos Tsitsikas, para. 45. 